Рекомендована д. фрармац. наук, профр. О. М. Заліською

УДК 615.281.8+616.98:578.828

DOI 10.11603/2312-0967.2018.1.8696

\title{
АНАЛІЗ ПРИЗНАЧЕНЬ СХЕМ АНТИРЕТРОВІРУСНОЇ ТЕРАПІЇ ВІЛ-ІНФІКОВАНИМ ОСОБАМ В УКРАÏH
}

\section{(C) I. O. Федяк}

\author{
ДВНЗ «Івано-Франківський національний медичний університет» \\ Irynaf@tvnet.if.ua
}

\begin{abstract}
Мета роботи. Провести аналіз призначень схем антиретровірусної терапії (АРТ) у реальній практиці людей, які живуть з ВІЛ (ЛЖВ), у 12-ти областях України та порівняти отримані результати з даними національного Звіту про надання АРТ ВІЛ-інорікованим особам.

Матеріали і методи. Використано 1200 карт диспансерного нагляду за ВІЛ-інфікованою особою Ф030-5/о, отриманих із 12-ти обласних СНІД-центрів Вінницької, Дніпропетровської, Запорізької, Івано-Франківської, Львівської, Миколаївської, Одеської, Рівненської, Тернопільської, Харківської, Херсонської областей та м. Києва у липні-листопаді 2016 р. (зі збереженням таємниці особистих даних ЛЖВ); дані Звіту про надання АРТ ВІЛінфікованим Центру громадського здоров'я МОЗ України; методи: частотний аналіз, АВС-аналіз призначень.

Результати й обговорення. П'ять схем АРТ є основними у призначеннях ЛЖВ в Україні - 1л: TDF+FTC(3TC)+EFV (39,0 \% за Звітом / 36,4 \% у вибірці), 1д: AZT+3TC+LPV/r (15,0 \% / 17,5 \%), 1a: AZT+3TC+EFV (14,2 \% / 13,0 \%), 10: TDF/FTC+LPV/r (8,9 \% / 9,0 \%), 1п: ABC+3TC+LPV/r (6,2 \% / 6,5 \%), оскільки їх сумарно приймали 83,26 \% / 82,42 \% лжВ.

Висновки. За результатом власних досліджень, 1200 лжВ 1777 раз призначали схеми АРТ. 3 усіх хворих -66,17 \% залишалися на первинній схемі АРТ першого ряду, а їі заміни відбувалися від одного (23,5 \%) до п'яти (0,17 \%) раз. Схема APT, рекомендована ВОО3, була лідером призначень (36,44 \%): TDF+FTC+EFV найчастіше призначали у Запорізькій (57 \%), Івано-Франківській (49\%), Рівненській (40 \%), Одеській (24 \%), Львівській (23 \%) областях. На другому місці - схема 1д: AZT+3TC+LPV/r (17,5 \%), яка була лідером у Херсонській (31 \%) та розділила лідерство зі схемою $1 л$ у Миколаївській (24 \%) областях.
\end{abstract}

Ключові слова: ВІЛ-інфекція/СНІД; лЖВ; карта диспансерного нагляду за ВІЛ-інфікованою особою Ф030-5/о; антиретровірусна терапія; реальні дані.

Вступ. ВІЛ-інфекція - це хвороба, що розвивається через тривалу персистенцію вірусу імунодефіциту людини (ВІЛ) і перебігає у вигляді повільно прогресуючої дисфункції імунної системи. Смерть особи, зараженої ВІЛ, настає через ускладнення, спричинені опортуністичними інфекціями і злоякісними пухлинами, які характеризують синдром набутого імунодефіциту (СНІД). ВІЛ призводить до тяжких соціальноекономічних і демографрічних наслідків, оскільки більшість ЛЖВ є особами працездатного репродуктивного віку [1-3]. Україна, на жаль, займає одне з перших місць серед країн Східної Європи за темпами поширення ВІЛ-інфекції та СНІДу [4]. За період 19872017 рр. в Україні офріційно зареєстровано 315618 випадків ВІЛ-інфекції, у тому числі 102205 випадків захворювання на СНІД та 45074 - смерті від захворювань, зумовлених СНІДом [5].

3 часу появи у 1996 р. потужної комбінованої антиретровірусної терапії (АРТ) лікування хворих з ВІЛіноекцією безперервно вдосконалюється. За допомогою сучасних схем АРТ повне вилікування від ВІЛінфекції неможливе, однак АРТ спроможна забезпе- чити вірусологічну супресію до рівня, який не визначається за допомогою сучасних тест-систем. Через це застосування АРТ різко знизило ВІЛ-асоційовану захворюваність і смертність та перетворило клінічний перебіг ВІЛ-інфрекції у хронічний, контрольований стан [6].

АРТ першого ряду відповідно до рекомендацій Всесвітньої організації охорони здоров'я (ВОО3) повинна включати 2 нуклеозидних інгібітори зворотної траснкриптази та один ненуклеозидний інгібітор зворотної транскриптази. На сьогодні пріоритетною схемою для початку терапії є схема під шифром 1 л: mенофовір (TDF) + емтрицитабін (FTC) / або ламівудин (3TC) + ефравіренз (EFV) у вигляді комбінованого лікарського препарату (ЛП) 3 фріксованими дозами [2]. Однією з основних рекомендацій ВООЗ $є$ заборона на використання ставудину в схемах 1 ряду, зважаючи на його доведену високу токсичність [7].

АРТ в Україні дорослим пацієнтам надається відповідно до Клінічного протоколу антиретровірусної терапії ВІЛ-інфрекції у дорослих та підлітків, затвердженого наказом Міністерства охорони здоров'я

ISSN 2312-0967. Фармацевтичний часопис. 2018. № 1 
(МО3) Україні від 12.07.2010 № 551 (надалі Протокол) [8]. Через появу нових рекомендацій ВООЗ щодо початку АРТ оновлення вітчизняних підходів до лікування регламентуються наказом МОЗ України від 22.12.2015 № 887 [9]. Відповідно до них АРТ рекомендується всім ЛЖВ з метою зниження ризику прогресування хвороби і профрілактики передачі ВІЛ, незалежно від кількості CD4-лімфроцитів. Запровадження нових рекомендацій ВООЗ щодо лікування за допомогою АРТ набуває багатьох переваг у боротьбі $з$ ВІЛ/СНІДом, а caме [7]:

- АРТ стає більш безпечною, простішою та економічно доступнішою;

- покращення якості та подовження тривалості життя хворих;

- використання АРТ запобігає передачі ВІЛ статевим шляхом та може слугувати методом профрілактики для незаражених осіб.

Станом на 01.01.2017 р. в Україні АРТ отримували 74780 пацієнтів (за кошти державного бюджету 41 910, кошти Глобального фонду для боротьби зі СНІДом, туберкульозом та малярією - 24 567, Надзвичайного плану президента США по боротьбі з ВІЛ (PEPFAR) - 8303 осіб) (не включені АР Крим, м. Севастополь, зона АТО Донецької та Луганської областей) [5].

Водночас є дані, що 34 \% ЛЖВ в Україні, які проходили АРТ, є носіями мутації ВІЛ, стійкої до тенофовіру (TDF), ключового ЛП АРТ. Окрім того, цей ЛП є однією з основ доконтактної профрілактики ВІЛ, що може стати в Україні неефективною. Для порівняння: серед населення Європи в цілому частка людей з такою мутацією ВІЛ становить менше 10 \%. Причини цього явища ще потребують вивчення [10]. Тому дослідження ефрективності та доступності АРТ для ЛЖВ в Україні є актуальним завданням.

Роль АРТ у протидії ВІЛ / СНІДу висвітлені у наукових працях Нізової Н. М. та співавт. [11], В. А. Марциновської та співавт. [12], О.К. Дуди [2], В. С. Гойдик та співавт. [13], Н. Г. Гойди, О. Г. Єщенко [6], Л. Р. Шостакович-Корецької та співавт. [14] та ін. Фармакоекономічним дослідженням АРТ присвячені публікації У. Я. Янишин [15], А. І. Бойка [16], А. С. Немченко та співавт. [17].

Однак в Україні не була здійснена оцінка підходів до використання АРТ лЖВ на основі великої кількості реальних клінічних даних. Тому для проведення наукових ініціатив щодо розробки фрармацевтичної складової у системі протидії ВІЛ-інфрекції / СНІДу було укладено договір про співпрацю від 18.05.2016 р. між ДУ «Український центр контролю за соціально небезпечними хворобами МОЗ України» (тепер ДУ «Центр громадського здоров'я МОЗ» (ЦГЗ) та ДВНЗ «Івано-Франківський національний медичний університет». Для виконання умов договору проведено аналіз призначень схем АРТ у картах диспансерного нагляду за ВІЛ-інфікованою особою 12-ти регіональ- них центрів профрілактики та боротьби 3 ВІЛіноекцією / СНІДом (СНІД-центрів) [18].

Мета роботи - провести аналіз призначень схем АРТ у реальній практиці лЖВ у 12-ти областях України та порівняти отримані результати з даними національного Звіту про надання АРТ ВІЛ-інсрікованим особам.

Матеріали і методи. Об'єктом аналізу стали підходи до призначення АРТ в Україні, а предметом карти диспансерного нагляду за ВІЛ-інфікованою особою Ф030-5/о (n=1 200). Особи перебували на обліку у закладах охорони здоров'я (303), що здійснюють медичний нагляд за лЖВ, 12-ти областей України за період липень-листопад 2016 року. Серед регіонів дослідження представлені області з дуже високою поширеністю ВІЛ: Одеська (830,2 осіб на 100 тис. населення станом на 01.01.2017 р.), Дніпропетровська $(815,1)$, Миколаївська $(728,4)$; високим поширенням: м. Київ $(409,5)$, Херсонська $(399,3)$, Запорізька $(250,7)$; середнім - Вінницька $(166,6)$, Рівненська $(153,1)$, Харківська $(138,6)$, Львівська $(129,6)$; відносно низьким: Тернопільська $(93,0)$, Івано-Франківська $(69,2)$. У кожному СНІД-центрі було опрацьовано по 100 карт лЖВ, які приймали АРТ. Карти для аналізу отримано методом суцільної вибірки із закриттям особистих даних ЛЖВ.

Дослідження проведено методом частотного аналізу призначених лікарями схем АРТ у картах Ф0305/о і паралельно - в оприлюдненому на сайті УГЗ Звіті про надання АРТ ВІЛ-інфрікованим особам в Україні станом на 01.01.2017 р. (надалі Звіт) [19]. До результатів частотного аналізу - 2-х рядів схем АРТ, розміщених за зменшенням частки кожної схеми, був використаний метод АВС-аналізу за принципом Парето: групу А за частотою призначень склали схеми, які сукупно були призначені близько 80 \% ВІЛінфрікованим особам, групу В - $15 \%$, групу С - 5 \% лЖВ.

Результати й обговорення. Результати аналізу вивчення пріоритетності серед схем АРТ, призначених 1200 ЛЖВ, які знаходились на обліку у СНІДцентрах у 12-ти регіонах, подано в таблиці 1.

Отже, за вивченням даних § 17 Контрольних карт диспансерного нагляду за ВІЛ-інфрікованою особою «Проведення антиретровірусної терапії», а саме: схеми АРТ (комбінація препаратів) на останню дату призначення, встановлено, що 1200 хворих у липнілистопаді 2016 р. повинні були приймати призначені лікарями 29 схем АРТ. Рекомендована ВООЗ схема 1л була лідером 3 часткою 36,44 \% - ії приймали 437 лжВ віком від 18 р. і старше. Вона призначена у 2-х модифікаціях: TDF+FTC+EFV та TDF+3TC+EFV. Першу - записано у картах 26,6 \% ВІЛ-інфрікованих, саме вона була найуживанішою серед схем. Однак цю першість забезпечили усього 5 із 12 СНІД-центрів - Запорізької (57 \%), Івано-Франківської (49\%), Рівненської (40 \%), Одеської (24\%), Львівської (23 \%) областей.

ISSN 2312-0967. Pharmaceutical review. 2018. № 1 
Якщо сумарно розглядати схему 1л у 2-х варіантах, то вона стає лідером призначень у 11 областях (окрім Херсонської).

На 2-у місці за призначеннями загалом - схема 1д: AZT+3TC+LPV/r (17,5 \%). Вона була лідером у Херсонській (31 \%) та розділила лідерство зі схемою 1л у Миколаївській (24 \%) областях, ще у 5-х областях знаходилася на 2-й сходинці: Тернопільській (33 \%), Дніпропетровській (22 \%), Львівській (19\%), Одеській (17\%), Івано-Франківській (12\%). На 3-у місці загалом - схема 1a: AZT+3TC+EFV (13\%), її також часто призначали у Харківській (23 \%), Вінницькій (20 \%), Миколаївській (17\%), Рівненській (12\%) областях (табл. 1).

ще 2 схеми APT - 10: TDF+FTC+LPV/r (9,0 \%) та 1п: ABC+3TC+LPV/r (6,5 \%) - увійшли до п'ятірки схем-лідерів, які сукупно споживали 82,42 \% пацієнтів. Водночас 11 серед 29 схем АРТ були призначені усього одній, 4 схеми - двом особам. Тому у подальшому до ряду схем АРТ був використаний принцип Парето (табл. 2).

Отже, АВС-аналіз виявив, що 5 перших схем, частка яких у сукупності схем була 17,24 \%, забез- печили 82,42 \% призначень, вони і сорормували групу А за частотою використання. Ще 3 схеми (10,35 \%), які були призначені 12,92 \% пацієнтів, склали групу В; 21 схема були використана у 4,66 \% випадків, однак серед усіх схем АРТ їх частка становила $72,41 \%$ - вони увійшли до групи С за частотою споживання, кожну 3 них було призначено менше 1 \% лЖВ (табл. 1).

Тому на наступному етапі дослідження був проведений аналіз Звіту про надання АРТ лЖВ в Україні станом на 01.01.2017 р., оприлюдненому на офріційному сайті УГЗ [20]. Аналіз Звіту представлений у таблиці 3 лише у розрізі пацієнтів, які спостерігалися у закладах МO3 та Національної академії медичних наук (НАМН) та осіб, віком від 18 років і старші, оскільки вибірка власних досліджень обмежилася лише цією категорією ЛЖВ.

Отже, за даними Звіту у закладах МO3 та НАMH України станом на 01.01.2017 р. 69689 осіб приймали 58 схем АРТ, з яких 8 схем - охопили 96,27 \% лЖВ і увійшли до груп А і В за частотою призначень у Звіті (табл. 3).

Таблиця 2. Розподіл досліджуваних схем АРТ за принципом Парето

\begin{tabular}{|c|c|c|c|c|}
\hline $\begin{array}{c}\text { Група } \\
\text { схем }\end{array}$ & $\begin{array}{c}\text { Кількість осіб, } \\
\text { які їх приймали }\end{array}$ & $\begin{array}{c}\text { Частка осіб, } \\
\%\end{array}$ & $\begin{array}{c}\text { Кількість схем, які забезпечили кожну } \\
\text { групу }\end{array}$ & $\begin{array}{c}\text { Частка схем, } \\
\%\end{array}$ \\
\hline A & 989 & 82,42 & 5 & 17,24 \\
\hline В & 155 & 12,92 & 3 & 10,35 \\
\hline C & 56 & 4,66 & 21 & 72,41 \\
\hline
\end{tabular}

Таблиця 3. Порівняльний аналіз даних власних досліджень та офіційного Звіту про надання АРТ ВІЛ-інфрікованим особам в Україні станом на 01.01.2017 р. (групи А і В за розподілом Парето)

\begin{tabular}{|c|c|c|c|c|c|c|c|c|}
\hline № & & Схеми АРТ & 1 ряд & 2 ряд & 3 ряд & $\begin{array}{c}\text { Всього } \\
\text { ЛЖВ за } \\
\text { Звітом } \\
\text { (осіб) }\end{array}$ & $\begin{array}{r}\% \text { ЛЖВ на } \\
\text { схемі АРТ } \\
\text { за Звітом }\end{array}$ & $\begin{array}{c}\text { \% ЛЖВ на } \\
\text { схемі за } \\
\text { власними } \\
\text { даними }\end{array}$ \\
\hline \multicolumn{9}{|c|}{$A$} \\
\hline \multirow[t]{3}{*}{1} & \multirow[t]{3}{*}{$1 л$} & \multirow{2}{*}{$V^{\text {B Т.Ч. }}$} & 26841 & 343 & 2 & 27186 & 39,0105 & 36,4166 \\
\hline & & & 21774 & 300 & 2 & 22076 & 31,6779 & 26,5833 \\
\hline & & TDF+3TC+EFV & 5067 & 43 & 0 & 5110 & 7,3326 & 9,8333 \\
\hline 2 & 1 д & $\mathrm{AZT}+3 \mathrm{TC}+\mathrm{LPV} / \mathrm{r}$ & 9842 & 640 & 1 & 10483 & 15,0425 & 17,5000 \\
\hline 3 & $1 \mathrm{a}$ & $\mathrm{AZT}+3 \mathrm{TC}+\mathrm{EFV}$ & 9827 & 47 & 0 & 9874 & 14,1687 & 13,0000 \\
\hline 4 & 10 & TDF/FTC+LPV/r & 5393 & 773 & 7 & 6173 & 8,8579 & 9,0000 \\
\hline 5 & $1 \pi$ & $\mathrm{ABC}+3 \mathrm{TC}+\mathrm{LPV} / \mathrm{r}$ & 3562 & 740 & 4 & 4306 & 6,1789 & 6,5000 \\
\hline \multicolumn{3}{|c|}{ Усього за групою А } & 55465 & 2543 & 14 & 58022 & 83,2585 & 82,4166 \\
\hline \multicolumn{9}{|c|}{ B } \\
\hline 6 & $2 \mathrm{e}$ & TDF+3TC+LPV/r & 3241 & 633 & 4 & 3878 & 5,5647 & 5,7500 \\
\hline 7 & $1 \pi$ & $A B C+3 T C+E F V$ & 3288 & 140 & 0 & 3428 & 4,919 & 4,6667 \\
\hline 8 & 16 & $\mathrm{AZT}+3 \mathrm{TC}+\mathrm{NVP}$ & 1751 & 8 & 0 & 1759 & 2,5241 & 2,5000 \\
\hline \multicolumn{3}{|c|}{ Усього за групою В } & 8280 & 781 & 4 & 9065 & 13,0078 & 12,9167 \\
\hline \multicolumn{3}{|c|}{ Усього за групою С } & 1897 & 415 & 290 & 2602 & 3,7337 & 4,6667 \\
\hline \multicolumn{3}{|c|}{ Разом } & 65642 & 3739 & 308 & 69689 & 100,00 & 100,00 \\
\hline
\end{tabular}

ISSN 2312-0967. Pharmaceutical review. 2018. № 1 
За власними даними, групи А і В сукупно становили 95,37 \% призначень, тобто різниця між національним рівнем та рівнем вибірки із 1200 осіб складає 0,9 \%. Розбіжності незначні, якщо брати до уваги, що вибірка реальних даних становила 1,72 \% усіх ЛЖВ в Україні на АРТ у системі МОЗ і НАМН. Водночас насторожує нижчий рівень схеми 1 л, рекомендованої ВООЗ в аналізованій вибірці $(36,42 \%)$ порівняно із даними Звіту (39,01 \%). Також виявлено, що 11 схем АРТ, присутніх серед досліджуваних диспансерних карт лЖВ, не знайшли відображення у Звіті.

Розподіл схем АРТ у Звіті та реальних даних було продовжено за рядами. Перша схема лікування ВІЛінфекції - схема АРТ 1 ряду, є найважливішою. Нова схема АРТ, яка призначається після підтвердження неефективності однієї схеми, називається схемою АРТ 2 ряду. У разі підтвердження невдачі в лікуванні за схемою АРТ 2 ряду за вірусологічними, імунологічними та клінічними критеріями, йде мова про призначення схеми АРТ 3 ряду [8]

На рисунку 1 показано співвідношення між рядами схем АРТ згідно зі Звітом.

Отже, за даними Звіту, 94,19 \% ЛЖВ в Україні отримували схеми АРТ першого ряду. Відповідно до результатів аналізу офріційних даних (табл. 3), розподіл за рядами 8-ми схем, які сорормували групи А і В за частотою використання, становив: для осіб на АРТ 1-го ряду - 97,11\%; 2-го ряду - 88,9 \% і 3-го $5,84 \%$.
Частка схеми 1 л серед схем першого ряду на рівні 40,89\%, як і різноманітність схем у Звіті (58) не є позитивним показником у підходах до призначення АРТ в Україні. Особливо це стосується пацієнтів першого ряду, для яких ВООЗ рекомендує пріоритетну схему - 1 л, називаючи її бажаною. Тому консультанти ВОО3 в Україні [20] разом з вітчизняними фрахівцями обговорюють питання, наскільки безпечно, з медичної точки зору, змінювати склад схем АРТ першого ряду для решти 59,11 \% пацієнтів, щоб більше число їх отримувало схему 1 л. Був досягнутий консенсус про те, що така можливість $є$ реальною для багатьох ЛЖВ (ймовірно 60-90 \%). Це призведе і до суттєвої економії коштів: за приблизними підрахунками вартість одного року терапії для одного хворого оцінюється в 360 дол. США, хоча цю суму реально знизити до 120-140 дол. США [20].

За результатами дослідження доцільно рекомендувати починати перехід на схему АРТ, рекомендовану ВОО3, зі зменшенням ваги у використанні схем класу C, а опісля - класу В (див. табл. 3). Однак для того, щоб ініціювати оптимізацію схем АРТ на національному рівні, необхідна наявність однакових підходів щодо її призначення у регіонах. Тому на рисунку 2 подано розподіл часток ЛЖВ за кількістю призначених їм схем АРТ у всій вибірці реальних клінічних даних, на рисунку 3 - за областями аналізу.

Отже, як свідчить результат вивчення частоти заміни початкової схеми АРТ (рис. 2), 66,17 \% лЖВ із

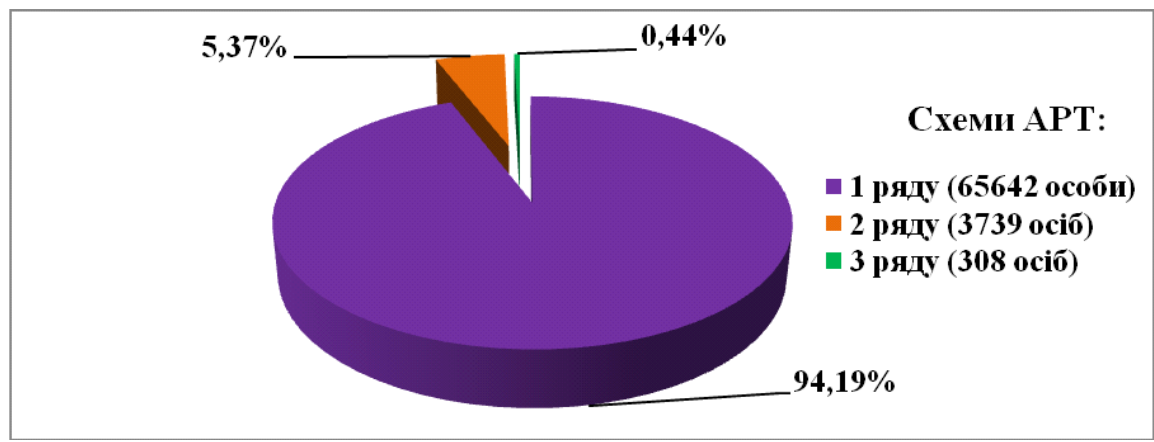

Рис. 1. Розподіл схем АРТ за рядами за даними Звіту про надання АРТ ВІЛ-інфікованим особам в Україні станом на 01.01.2017 p.

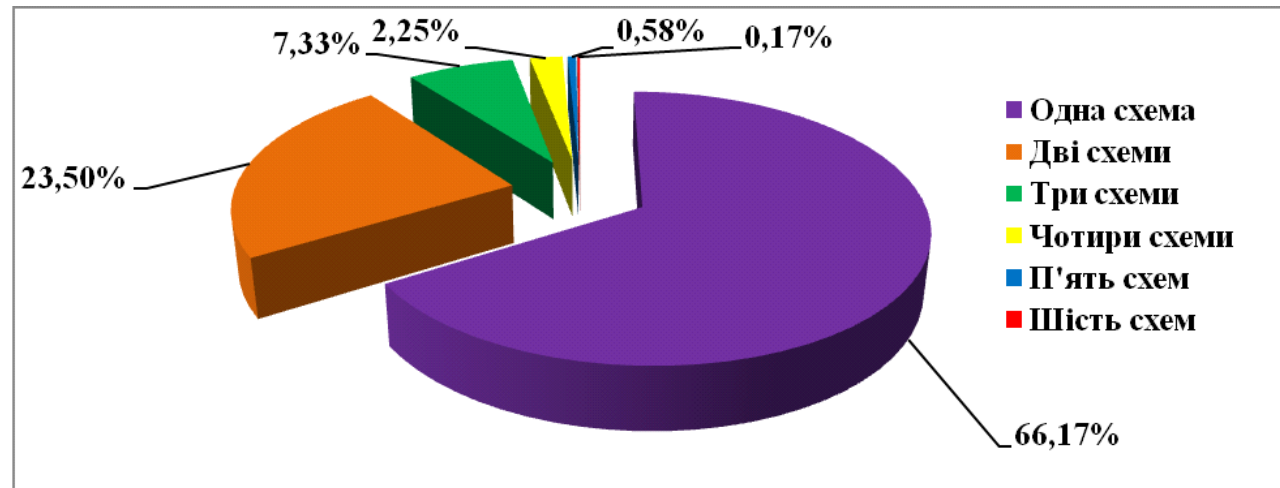

Рис. 2. Загальний поділ диспансерних карт за кількістю призначених схем АРТ.

ISSN 2312-0967. Фармацевтичний часопис. 2018. № 1 


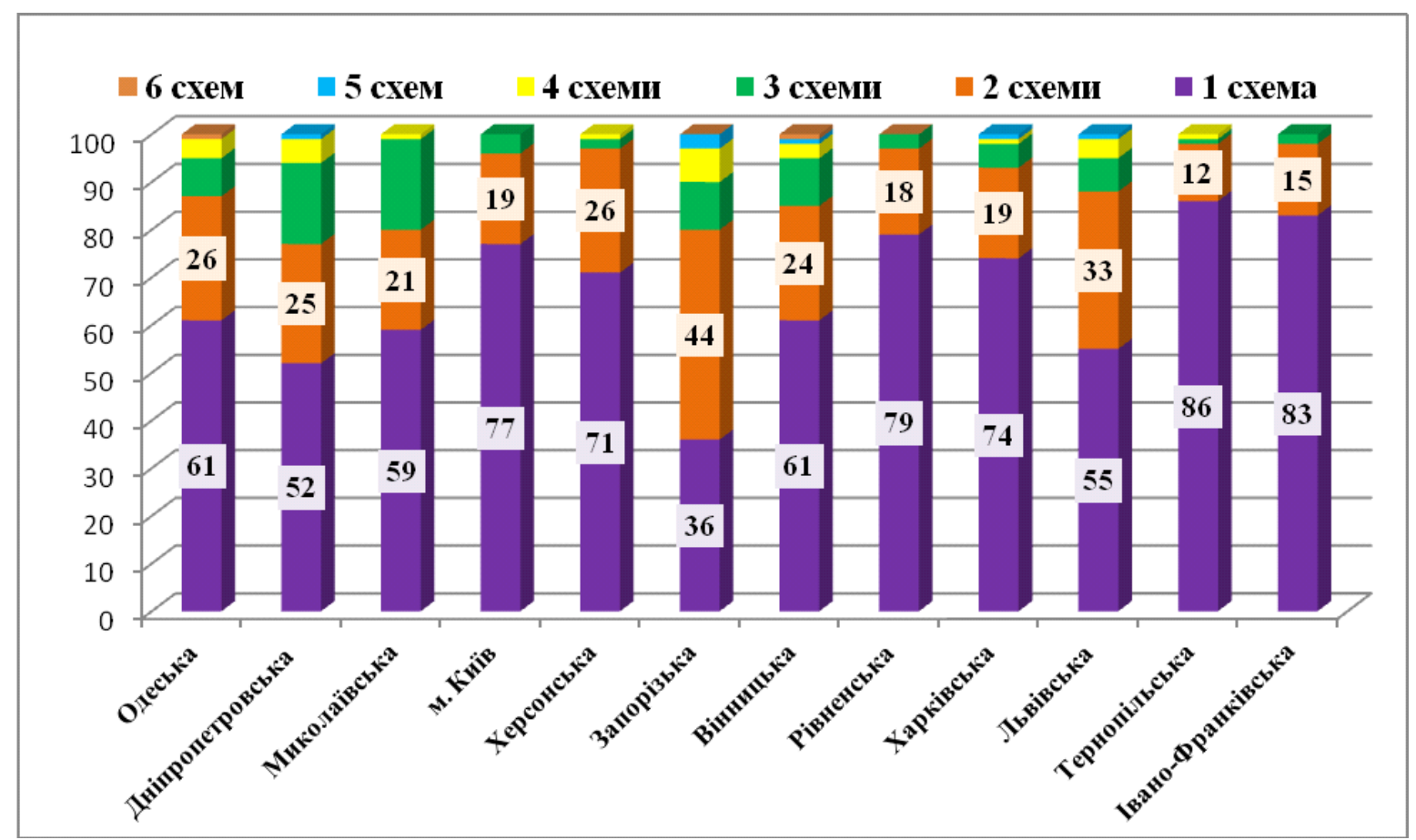

Рис. 3. Розподіл часток диспансерних карт за кількістю призначених ЛЖВ схем АРТ за областями дослідження (\%).

загальної сукупності (n=1 200) не змінювали її та продовжують приймати першу схему АРТ першого ряду. Один раз міняли схему терапії 23,50 \% пацієнтів. Проте схема АРТ, яка модифікована у випадку розвитку токсичності або побічних реакцій, із заміною окремих ЛП, як правило, в межах їх класів, називається заміненою схемою першого ряду [8]. Практику видозмінювати початкову схему АРТ найчастіше демонстрували у Запорізькому (66 \%), Дніпровському (48\%), Львівському (45 \%) СНІД-центрах, оскільки лише 34 \%, 52 \%, 55 \% пацієнтів, відповідно, які спостерігалися у цих 303, залишалися на ній, а найвища частка хворих, які не змінювали першу схему першого ряду, спостерігалась у Тернопільській (86 \%), Івано-Франківській (83 \%), Рівненській (79 \%) областях та м. Києві (77 \%). Досвід прийому 2-х схем АРТ найбільший у ВІЛ-інфрікованих із Запорізької (44\%) та Львівської (33 \%), 3-х схем - Миколаївської (19 \%) та Дніпропетровської (17 \%) областей. Найбільше число, а саме: 6 схем АРТ споживали по одній особі із Одеської і Вінницької областей. Загалом 1200 ВІЛінфікованих пацієнтів прийняли 1777 схем АРТ: від 117 у Тернопільській до 197 у Запорізькій областях, тобто у середньому на одну ЛЖВ в Україні припадає по 1,5 схеми АРТ. Отже, результати цих досліджень показують відсутність єдиного підходу до призначення АРТ серед регіональних СНІД-центрів в Україні.

Висновки. 1. Проведено частотний та АВС-аналіз призначень схем антиретровірусної терапії ВІЛінфікованим пацієнтам за реальними клінічними даними, отриманими при опрацюванні 1200 карт диспансерного нагляду за ВІЛ-інорікованими особами, які знаходились на обліку у СНІД-центрах 12-ти регіонів із різною поширеністю ВІЛ-інфекції у липні-листопаді 2016 р., та за даними Звіту про надання АРТ ВІЛ-інфрікованим Центру громадського здоров'я МО3 України станом на 01.01.2017 р.

2. Виявлено, що 1200 ВІЛ-інфікованим пацієнтам 1777 раз призначалися схеми АРТ. На час дослідження ЛжВ отримували 29 раціонів терапії. 3 усіх пацієнтів - 66,17 \% залишалися на первинній схемі АРТ першого ряду, а її заміни відбувалися від одного $(23,5 \%)$ до п'яти $(0,17 \%)$ раз.

3. Встановлено, що і у вибірці реальних даних, і у Звіті п'ять схем АРТ $\epsilon$ основними для пацієнтів в Україні - 1л: TDF+FTC(3TC)+EFV (39,01 \% - за Звітом / 36,42 \% - за власними дослідженнями), 1д: AZT+3TC+LPV/r (15,0 \% / 17,5\%), 1a: AZT+3TC+EFV $(14,17 \% / 13,0 \%), 10:$ TDF/FTC+LPV/r (8,86 \% / 9,0 \%), 1п: ABC+3TC+LPV/r (6,18\% / 6,5 \%), які за принципом Парето було віднесено до групи А за частотою призначень (їх приймали 83,26 \% / 82,42 \% хворих). Ще 3 схеми АРТ сорормували групу В (13,01 \% / 12,92 \%), а до групи С (3,73 \% / 4,66 \%) увійшли 50 / 21 схема, що становили 86,21 \% / 72,41 \% усіх призначених раціонів АРТ. За даними Звіту, схему АРТ, рекомендовану ВОО3, серед схем першого ряду приймають всього 40,89 \% вітчизняних ЛЖВ.

4. Вибірка реальних даних становила 1,72 \% усіх ЛЖВ в Україні на АРТ у системі МОЗ і НАМН та була репрезентативною, оскільки розходження у частках 8-ми основних схем АРТ, порівняно зі Звітом, склало 0,9\%.

5. Власними дослідженнями виявлено розбіжність у пріоритетності схем АРТ та підходів до їх замін у 
розрізі регіонів. Так, схему APT TDF+FTC+EFV, рекомендовану ВОО3, найчастіше призначали у Запорізькій (57\%), Івано-Франківській (49\%), Рівненській (40 \%), Одеській (24\%), Львівській (23 \%) областях. На другому місці - схема 1д: AZT+3TC+LPV/r, яка була лідером у Херсонській (31\%) та розділила лідерство зі схемою 1л у Миколаївській (24 \%) областях. Найчастіше змінювали початкову схему АРТ у
Запорізькій (66 \%), найрідше - у Тернопільській (86 \%) та Івано-Франківській (83 \%) областях.

Перспективи подальших досліджень. Враховуючи актуальність тематики, доцільно продовжити вивчення реальних клінічних даних та стану закупівель лП для дослідження можливості переходу на схему АРТ, рекомендовану ВООЗ, більшого числа лЖВ в Україні.

\title{
АНАЛИЗ НАЗНАЧЕННЫХ СХЕМ АНТИРЕТРОВИРУСНОЙ ТЕРАПИИ ВИЧ-ИНФИЦИРОВАННЫМ ЛИЦАМ В УКРАИНЕ
}

\author{
И. О. Федяк \\ ГВУз «Ивано-Франковский национальный медицинский университет» \\ Irynaf@tvnet.if.ua
}

Цель работы. Провести анализ назначенных схем антиретровирусной терапии (APT) в реальной практике людей, живущих с ВИЧ (ЛЖВ), в 12 областях Украины и сравнение полученных результатов с данными национального Отчета о предоставлении АРТ ВИЧ-инорицированным лицам.

Материалы и методы. Использовали 1200 карт диспансерного наблюдения за ВИЧ-иноицированным лицом Ф030-5/о, полученные из 12-ти областных СПИД-центров Винницкой, Днепропетровской, Запорожской, ИваноФранковской, Львовской, Николаевской, Одесской, Ровенской, Тернопольской, Харьковской, Херсонской областей и г. Киева в июле-ноябре 2016 г. (с сохранением тайны личных данных ЛЖВ); данные Отчета о предоставлении АРТ ВИЧ-инфицированным Центра общественного здоровья МОЗ Украины; методы: частотный анализ, АВСанализ назначений.

Результаты и обсуждение. Пять схем АРТ являются основными в назначениях лЖВ в Украине - 1л: TDF + FTC (3TC) + EFV (39,0 \% за отчетом / 36,4 \% в выборке), 1д: AZT + 3TC + LPV / r (15 0 \% / 17,5 \%), 1a: AZT + 3TC + EFV (14,2 \% / 13,0 \%), 10: TDF / FTC + LPV / r (8,9 \% / 9,0 \%), 1п: ABC + 3TC + LPV / r (6,2 \% / 6,5 \%), поскольку их принимали 83,26 \% / 82,42 \% больных.

Выводы. По результатам собственных исследований 1200 лЖВ 1777 раз назначали схемы АРТ. Из всех больных - 66,17 \% оставались на первичной схеме АРТ первого ряда, а ее изменения происходили от 1-го (23,5 \%) до 5-ти $(0,17 \%)$ раз. Схема АРТ, рекомендованная BO3, была лидером назначений $(36,44 \%)$ : TDF+FTC+EFV чаще всего назначали в Запорожской (57 \%), Ивано-Франковской (49 \%), Ровенской (40 \%), Одесской (24 \%), Львовской (23 \%) областях. На втором месте - схема 1д: AZT+3TC+LPV/r (17,5\%), которая была лидером в Херсонской (31 \%) и разделила лидерство со схемой 1 л в Николаевской (24 \%) областях.

Ключевые слова: ВИЧ-инфекция / СПИД; ЛЖВ; карта диспансерного наблюдения за ВИЧ-инфицированным лицом Ф030-5/о; антиретровирусная терапия; реальные данные.

\section{ANALYSIS OF APPOINTMENT OF ANTIRETROVIRAL TREATMENT FOR HIV-INFECTED PERSONS IN UKRAINE}

\section{O. Fedyak}

Ivano-Frankivsk National Medical University

Irynaf@tvnet.if.ua

The aim of the work. Analysis of the designation of ART in real life in PLWH in 12 regions of Ukraine and comparison of the results with the data of the National Report on the provision of ART to HIV-infected individuals.

Materials and Methods. 1.200 dispensary cards of HIV-infected persons F030-5/o, received from 12 region AIDS centers in Vinnytsia, Dnipropetrovsk, Zaporizhzhia, Ivano-Frankivsk, Lviv, Mykolaiv, Odesa, Rivne, Ternopil, Kharkiv, Kherson and Kyiv in July-November 2016 (with the preservation of personal data of people living with HIV); data of the Report on the provision of ART to HIV-infected by the Center for Public Health of the Ministry of Health of Ukraine; methods: frequency analysis, $A B C$ analysis of assignments.

Results and Discussion. Five ART regimens are essential for the appointment of PLHIV in Ukraine - 1L: TDF + FTC (EF) $+\operatorname{EFV}(39.0 \%$ in the Report / $36.4 \%$ in the sample), 1d: AZT + 3TC + LPV / r (15.0 \% / 17.5 \%), 1a: AZT + 3TC + EFV

ISSN 2312-0967. Фармацевтичний часопис. 2018. № 1 
(14.2\% / 13.0\%), 10: TDF / FTC + LPV / r (8.9\% / 9.0\%), 1p: ABC + 3TC + LPV / r (6.2\% / 6.5\%), since they were $83.26 \%$ / $82.42 \%$ of patients in total.

Conclusions. As a result of our own research, 1200 PLWH 1777 times appointed ART regimens. Among all patients, $66.17 \%$ remained on the primary ART 1 series, and its changes from $1(23.5 \%)$ to $5(0.17 \%)$ times. The ART pattern recommended by WHO was the leader of appointments (36.44\%): TDF + FTC + EFV was most commonly prescribed in Zaporizhzhia (57\%), Ivano-Frankivsk (49\%), Rivne (40\%), Odesa (24\%), Lviv region (23\%). In the second place, the 1d pattern was AZT + ZTC + LPV / r (17.5\%), which was the leader in Kherson (31\%) and shared leadership with the $1 \mathrm{~L}$ scheme in Mykolaiv (24\%) regions.

Key words: HIV / AIDS; PLWH; card of the dispensary supervision for an HIV-infected person F030-5/o; antiretroviral therapy; real data.

\section{Список літератури}

1. HIV / AIDS. Fact sheet. Updated November 2017. [Electronic resource]. - Access mode : http://www.who.int/mediacentre/factsheets/fs360/en/.

2. Дуда О. К. Світові тенденції щодо застосування антиретровірусної терапії при ВІЛ-інфекції [Електронний ресурс] / О. К. Дуда // Мистецтво лікування. - 2013. № 8 (104). - С. 6-9. - Режим доступу: http://health-medix. com/articles/misteztvo/2013-10-14/svitovi_tendencii.pdf.

3. Про затвердження Загальнодержавної цільової соціальної програми протидії ВІЛ-інфекції / СНІДу на 2014-2018 роки : Закон України від 20.10.2014 р. №1708VII [Електронний ресурс]. - Режим доступу: http://zakon5.rada.gov.ua/laws/show/\%201708-18/page.

4. Андрейчин М. А. Проблема ВІЛ-інфрекції в Україні і участь лікарів загальної практики - сімейної медицини в її вирішенні [Текст] / М. А. Андрейчин // Інфекційні хвороби. - 2014. - № 4. - С. 7-12.

5. Ресурс ДУ «Центр громадського здоров'я МОЗ України» [Електронний ресурс]. - Режим доступу : https://phc.org.ua/pages/diseases/hiv_aids/treatment-andprevention/art.

6. Гойда Н. Г. Вплив застосування антиретровірусної терапії на перебіг епідемії ВІЛ-інорекції в Україн [Електронний ресурс] / Н. Г. Гойда, О. Г. Єщенко // Ліки України плюс. - 2015. - № 4 (25). - С. 5-8. Режим доступу : http://www.health-medix.com/articles/liki_ukr_ plus/2015-12-14/!2.pdf.

7. WHO. Consolidated guidelines on the use of antiretroviral drugs for treating and preventing HIV infection: recommendations for a public health approach - 2nd ed., 2016. -480 p. [Electronic resource]. - Access mode : //www.who. int/mediacentre/ factsheets/fs360/en/.

8. Про затвердження клінічного протоколу АРТ ВІЛ-інфекції у дорослих та підлітків : наказ МОЗ України від 12.07.2010 № 551 [Електронний ресурс]. - Режим доступу : http://old. moz.gov.ua/ua/print/dn_20100712_551.html.

9. Про затвердження Змін до Клінічного протоколу АРТ ВІЛ-інфекції у дорослих та підлітків : наказ МОЗ України від 22.12.2015 № 887 [Електронний ресурс]. - Режим доступу: http://www.moz.gov.ua/docfiles/dn_20151222_0887dod.pdf.

10. Сафраров А. Небезпечна мутація ВІЛ в Україні: третині хворих ліки не допомагають, 19.01.2018 [Електронний ресурс]. - Режим доступу : http://www. dw.com/uk/-42220559.

11. Аналіз індикаторів раннього попередження формування резистентності ВІЛ до антиретровірусних препаратів в Україні [Текст] / Н. М. Нізова, М. Г. Люльчук, Ю. В. Кобища [та ін.] // Туберкульоз, легеневі хвороби, ВІЛ-інфекція. - 2013. - № 1 (12). - С. 14-19.

12. Аналіз причин смерті ВІЛ-позитивних осіб на тлі широкого застосування антиретровірусної терапії в Україні [Текст] / В. А. Марциновська, І. В. Нгуєн, І. В. Кузін [та ін.] // Профрілактична медицина. - 2012. - № 3-4 (19). - С. 16-21. 13. Зміни у структурі захворюваності пацієнтів з ВІЛінфекцією/СНІДом на тлі поширення ВААРТ [Текст] / В. С. Гойдик, В.В.Шухтін, Н. С. Гойдик [та ін.] // Одеський медичний журнал. - 2013. - № 3. - С. 31-35.

14. Проблемні питання проведення антиретровірусної терапії у хворих на ВІЛ-інсрекцію [Текст] / Л. Р. Шостакович-Корецька, О. В. Шевельова, О. О. Волікова [та ін.] // Вісник соціальної гігієни та організації охорони здоров'я України. - 2017. - № 3 (73). - С. 51-57. 15. Янишин У. Я. Фармацевтичне забезпечення лікування сисрілісу, гонореї, ВІЛ / СНІДу [Текст] / У. Я. Янишин : автореф. дис. на здобуття наук. ступеня канд. фармац. наук: 15.00.01 / Львів. нац. мед. ун-тет ім. Д. Галицького, 2009. -24 c.

16. Бойко А. І. Фармакоекономічний аналіз інгібіторів протеази, що застосовуються для лікування ВІЛінфікованих пацієнтів в Україні [Текст] / А. І. Бойко // Фармацевтичний журнал. - 2010. - № 4. - С. 18-27.

17. Немченко А. С. Методика фрармакоекономічної оцінки нових технологій фрармакотерапії хворих на ВІЛ-інфекцію [Текст] / А. С. Немченко, К. Л. Косяченко, Ю В. Корж // Управління, економіка та забезпечення якості в фармації. - 2012. - № 1. - С. 72-77.

18. Федяк І. О. Дослідження медико-соціального портрету пацієнта і пріоритетності серед схем антиретровірусної терапії у вітчизняних регіональних центрах СНІДУ [Текст] / І. О. Федяк // Фармацевтичний журнал. - 2016. - № 6. - С. 40-49.

19. Загальна кількість осіб, які отримують АРТ в Україні станом на 01.01.2017 [Електронний ресурс]. - Режим доступу : https://phc.org.ua/uploads/ documents/85ec49/4 3667fb2ada28042da20850649130824.pdf.

20. Краткая выдержка из отчета профр. Йенса Лундгрена, Колаборативный Центр ВОЗ по вопросам ВИЧ и вирусных гепатитов, г. Копенгаген, Дания Оптимизация AРT в Украине: общие принципы с точки зрения общественного здравоохранения [Текст] // Профр. мед.: епідем., мікроб., вірус., паразит., інсрек. хв. - 2016. № 3-4 (27). - C. 174-176.

ISSN 2312-0967. Pharmaceutical review. 2018. № 1 


\section{References}

1. HIV / AIDS. Fact sheet. Updated November 2017 [Electronic resource]. World Health Organization, 2017. Available from: http://www.who.int/mediacentre/ factsheets/ fs360/en/. [Accessed February 2018].

2. Duda OK. [Critical trends in the use of antiretroviral therapy for HIV infection]. Mystetstvo likuvannia. 2013;8(104): 6-9. Ukrainian.

3. Zakon Ukrainy vid 20.10.2014 №1708-VII «Pro zatverdzhennia Zahalnoderzhavnoi tsilovoi sotsialnoi prohramy protydii VIL-infektsii / SNIDu na 2014-2018 roky». Available from: http://zakon5.rada.gov.ua/laws/show/\%20 1708-18/page.

4. Andreichyn MA. [Problem of HIV-infection in Ukraine and participation of general practitioner - family medicine in its decision]. Infektsiini khvoroby. 2014;4: 7-12. Ukrainian.

5. Center for Public Health Ministry of Health of Ukraine. [Electronic resource, Ukrainian]. Available from: https://phc. org.ua/pages/diseases/hiv_aids/treatment-and-prevention/ art. [Accessed February 2018].

6. Hoida $\mathrm{NH}$, Yeshchenko $\mathrm{OH}$. [The influence of antiretroviral therapy on the epidemic of HIV infection in Ukraine Електронний ресурс]. Liky Ukrainy plius. 2015;4(25): 5-8. Ukrainian.

7. WHO. Consolidated guidelines on the use of antiretroviral drugs for treating and preventing HIV infection: recommendations for a public health approach - 2nd ed., 2016. Available from: http://www.who.int/mediacentre/ factsheets/ fs360/en/.

8. Nakaz MOZ Ukrainy vid 12.07.2010 № 551 «Pro zatverdzhennia klinichnoho protokolu ART VIL-infektsii u doroslykh ta pidlitkiv». Available from: http://old.moz.gov.ua/ua/ print/dn_20100712_551.html.

9. Nakaz MOZ Ukrainy vid 22.12.2015 № 887 «Pro zatverdzhennia Zmin do Klinichnoho protokolu ART VIL-infektsii u doroslykh ta pidlitkiv». Available from: http://www.moz. gov.ua/docfiles/dn_20151222_0887dod.pdf.

10. Safarov A. [Dangerous HIV mutation in Ukraine: a third of patients do not help drugs]. Available from: http://www. dw.com/uk/-42220559. [Accessed February 2018].

11. Nizova NM, Liulchuk MH, Kobyshcha YuV, Voronova KV. [Analysis of early warning indicators for the formation of HIV resistance to antiretroviral drugs in Ukraine]. Tuberkuloz, lehenevi khvoroby, VIL infektsiia. 2013;1(12): 14-9. Ukrainian. 12. Martsynovska VA, Nhuien IV, Kuzin IV, Buhaienko NS, Serheeva TA. [Analysis of causes of death of HIV-positive persons against the background of the wide use of antiretroviral therapy in Ukraine]. Profilaktychna medytsyna. 2012;3-4(19): 16-21. Ukrainian.

13. Hoidyk VS, Shukhtin VV, Hoidyk NS, Hozhenko AI [Changes in the morbidity structure of patients with HIV / AIDS in the context of HAART proliferation] Odeskyi medychnyi zhurnal. 2013;3: 31-5. Ukrainian.

14. Shostakovych-Koretska LR, Shevelova OV, Volikova OO, Lytvyn Klu, Kushnierova OA [Issues of antiretrovirai therapy in HIV-infected patients]. Visnyk sotsialnoi hihiieny ta orhanizatsii okhorony zdorovia Ukrainy. 2017;3(73): 517. Ukrainian.

15. Yanyshyn UYa. Pharmaceutical support for the treatment of syphilis, gonorrhea, HIV / AIDS [abstract of dissertation]. Lviv; 2009. Ukrainian.

16. Boiko Al. [Pharmacoeconomic analysis of protease inhibitors used for the treatment of HIV-infected patients in Ukraine]. Farmatsevt. zhurnal. 2010;4: 18-27. Ukrainian. 17. Nemchenko AS, Kosiachenko KL, Korzh YuV. [The method of pharmacoeconomic evaluation of new technologies of pharmacotherapy for patients with HIV infection]. Upravlinnia, ekonomika ta zabezpechennia yakosti v farmatsii 2012;1: 72-7. Ukrainian.

18. Fediak IO. [Research of medical and social portrait of the patient and priority among schemes of the antiretroviral therapy in the national regional AIDS centers]. Farmatsevt zhurn. 2016;6: 40-9. Ukrainian.

19. Zahalna kilkist osib, yaki otrymuiut ART v Ukraini stanom na 01.01.2017 Available from: https://phc. org.ua/uploads/documents/85ec49/ 28042da20850649130824.pdf.

20. Brief excerpt from the report prof. Jens Lundgren, WHO Collaborating Center on HIV and Viral Hepatitis, Copenhagen, Denmark Optimization of ART in Ukraine: General Public Health Principles. Profilaktychna medytsyna: epidemiolohiia, mikrobiolohiia, virusolohiia, parazytolohiia, infektsiini khvoroby. 2016;3-4: 174-6. Russian. 